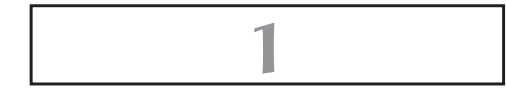

\title{
O ESTADO INTERVENCIONISTA
}

\subsection{DO “LIBERALISMO" AO INTERVENCIONISMO ESTATAL E A ORDEM ECONÔMICA}

Desde a transferência, pelo povo, do exercício do poder para um representante, dotado de força suficiente para impor determinados comportamentos e solucionar conflitos em busca do bom funcionamento da sociedade, com a constituição do que se denomina atualmente Estado, verifica-se sua intervenção na esfera de atividade do particular.

Observam-se, daí por diante, formas distintas de intervenção do Estado na sociedade e na economia.

De acordo com Michel Foucault, é no século XVII (1601-1700) que se tornou, de fato, pertinente na história das sociedades ocidentais o modelo de intervenção estatal destinado a propiciar um melhor viver e o bem-estar dos indivíduos. Tem como causa a relação entre a razão de Estado e o privilégio urbano, entre a polícia e o primado da mercadoria, tomando a governamentalidade do Estado significado "pela materialidade fina da existência e da coexistência humana, pela materialidade fina da troca e da circulação", passando o comércio a ser visto como o instrumento principal da força do Estado'.

1 FOUCAULT, Michel. Segurança, território, população: curso dado no Collège de France (1977-1978). Tradução de Eduardo Brandão e revisão de Claudia Berliner. São Paulo: Martins Fontes, 2008. p. 456. 
Ainda que a história mostre o Estado sempre atuando no domínio econômi$\mathrm{CO}^{2}$, as atuais ideias intervencionistas de fato surgiram na classe intelectual antes da Primeira Guerra Mundial (1914-1918). No entanto, é em decorrência dessa Guerra Mundial e do progresso econômico despontado com a Revolução Francesa de $1789^{3}$ que muitos sugerem ser esse o marco de eclosão do Estado Intervencionista, o que comumente se denominou "economia de guerra", pois todo o planejamento econômico-financeiro de um Estado passa a girar em torno de suas necessidades militares.

A intervenção estatal passa a ser marcada pela necessidade dos Estados em auferir renda suficiente para manter seu poderio bélico e evitar a dependência ou submissão aos ditames de seu opositor.

Os fatos apontados remetem, ainda que inaceitáveis nos dias de hoje, às liçōes de Maquiavel $^{4}$, em particular quando trata da conquista, da manutenção do poder e das consequências sofridas pelos Estados dominados como fundamento de sua teoria:

Quando estes Estados conquistados estão acostumados a viver com suas leis e em liberdade, querendo, há três modos para mantê-los. O primeiro é aniquilá-los. O outro é residir neles. O terceiro é deixá-los viver com suas leis, retirando uma renda e criando internamente um governo de poucos que manterá o consenso. Tal governo, consciente do fato de existir pela vontade do príncipe, sabe que depende de sua benevolência e poder e tem todo o interesse em agir de modo a conservar a situação. O modo mais fácil de manter uma cidade livre é confiar o seu governo aos próprios cidadãos.

Motivado pela revolução do modo de pensar e diante de uma nova concepção das instituições públicas, referido modelo econômico, intervencionista, toma força no pós-guerra, ou seja, em tempos de paz, quando então passa a representar o ideal de uma economia planificada e um modelo a ser seguido por vários Estados.

2 A propósito, vale conferir a palestra proferida no plenário do Tribunal Regional Federal da $4^{\mathrm{a}}$ Região. (FERREIRA FILHO, Manoel Gonçalves. A intervenção do estado no domínio econômico e a Constituição de 1988. Revista do Tribunal Regional Federal: 4a Região, ano 24, n. 82, p. 61-74, 2013, passim).

3 Em face de uma grave crise financeira, decorrente da participação na Guerra da Independência dos Estados Unidos da América, na Guerra dos Sete Anos e dos elevados custos da Corte de Luís XVI, instaurou-se na França um período de intensa agitação política e social que culminou na proclamação da Primeira República francesa (1792), na supressão de privilégios feudais, aristocráticos e religiosos e na eclosão de novos princípios: liberdade, igualdade e fraternidade.

4 MAQUIAVEL, Nicolau. O principe. 22. reimpressão. Tradução de Maria Lucia Cumo. Rio de Janeiro: Paz e Terra, 1996. p. 29. 
Esse modelo intervencionista contrapôs-se ao modelo comunista implantado na União Soviética e na Alemanha, que se mostrou incapaz de gerar o almejado bem-estar social e cujos problemas enfrentados devastaram suas economias. É emblemático, por exemplo, o ocorrido na extinta União Soviética, onde passaram a imperar a pobreza e a fome em massa, assim como na Alemanha, totalmente destruída, em que se via a devastação decorrente da hiperinflação e das indenizações de guerra.

Posteriormente, com o advento da denominada "Crise de 1929" ou "Grande Depressão", considerado o pior e mais longo período de recessão econômica do século XX, verifica-se o avanço do modelo intervencionista do Estado em detrimento do Estado liberal.

Diante dos altos índices de desemprego, da grande queda do PIB de diversos países e da brusca depressão industrial, os Estados, de modo geral, veem-se obrigados a intervir para impulsionar a atividade econômica e recuperar os países das crises decorrentes do pós-Guerra.

No campo da macroeconomia despontam as ideias revolucionárias de John Maynard Keynes ${ }^{5}$, cujos ideais se fundam no estudo das medidas de intervenção do governo na economia, na busca pelo pleno emprego, no desenvolvimento econômico, na estabilização da moeda e na melhor distribuição da renda. O dirigismo estatal se coloca acima do protecionismo comercial, dando ênfase à Teoria Marxista, fundada na existência de uma sociedade de classes em que os interesses de seus membros se mostram antagônicos, opostos à realização do bem comum e à neutralização do Estado.

De acordo com André de Laubadère ${ }^{6}$, a crise econômica de 1929 constitui o grande fator circunstancial do intervencionismo. Passa-se a falar em economia dirigida e, a partir de 1930, nascem as primeiras intervenções econômicas do Estado, quando este assume o controle das importações e substitui a antiga política alfandegária impondo a utilização de licenças, a adoção de medidas restritivas no campo e a interferência nos transportes.

É ainda nesse período de entre guerras que surgem as sociedades de economia mista, oriundas da união de recursos públicos e privados, cuja fórmula até os dias atuais impera como verdadeiro instrumento de intervenção no domínio econômico. Veja-se:

KEYNES, John Maynard. Teoria geral do emprego, do juro e da moeda. Tradução de Manuel Resende. São Paulo: Saraiva, 2012. p. 85-95; 145-147; 221-229.

6 LAUBADÈRE, André de. Direito público económico. Traduzido por Maria Teresa Costa; revisto por Evaristo Mendes. Coimbra: Almedina, 1985. p. 40. 
No respeitante à economia mista, constituída pela reunião de capitais públicos e de capitais privados no seio das sociedades mistas, o período de entre as duas guerras foi ainda mais importante pois foi então que esta fórmula teve início; de resto viria a conhecer seguidamente uma história em "dentes de serra", marcada pela alternância de períodos de favor e períodos de desfavor. Surgiu então um domínio como terreno de eleição da economia mista $(. . .)^{7}$.

Em suma, com o fim da Primeira Guerra e antes do início da Segunda impôs-se a necessidade de reestruturação dos poderes do Estado, elevando o direito público sobre o direito privado, em que o Poder Executivo passa a se sobrepor aos Poderes Legislativo e Judiciário, pois se mostra determinante a promoção da paz e do bem-estar social.

Encarregado de promover a reestruturação das nações em crise, os Estados, por intermédio do Poder Executivo e de seus governantes, passam a intervir diretamente no domínio econômico. Orientados pelo interesse geral, deixa de subsistir a errônea concepção de que Estado e sociedade existam separadamente, conforme aponta Eros Roberto Grau ${ }^{8}$ :

Ao Estado, até o momento neoconcorrencial ou intervencionista - qualquer que seja o vocábulo ou expressão que se adote para designar a mudança de regime que marca, no sistema capitalista, a passagem do século XIX para o século XX - estava atribuída, fundamentalmente, a função de produção do direito e segurança. Para referir, em largos traços, o regime anterior, poderíamos afirmar, singelamente, que não se admitia a interferência do Estado na "ordem natural" da economia, ainda que lhe incumbisse a defesa da propriedade. Essa concepção porta em si a pressuposição de que ambos, Estado e sociedade, existissem separadamente um do outro, o que não é correto.

Surge, assim, o Estado moderno com a incumbência de atuar no campo econômico, promover a formação e a preservação do modo de produção; garantir o direito de propriedade e a liberdade de contratar; proteger o sistema de mercado contra efeitos secundários autodestrutíveis; assegurar as premissas da produção dentro da economia global, como, por exemplo, educação, transporte, comunicações, além de outros bens indispensáveis ao bem-estar social'.

Verifica-se que os profundos abalos da ordem econômica, decorrentes, sobretudo, de guerras e crises econômicas - particularmente após a Primeira Guerra Mundial -, impulsionaram as Constituiçôes à adoção de algumas características comuns.

7 LAUBADÈRE, André de. Direito público económico, p. 42.

8 GRAU, Eros Roberto. A ordem econômica na Constituição de 1988. 14. ed. São Paulo: Malheiros, 2010. p. 16.

9 GRAU, Eros Roberto. A ordem econômica na Constituição de 1988, p. 18. 
Consideradas parte do novo "constitucionalismo social”, essas Constituições incluíram, em boa parte dos Estados europeus e ao lado dos tradicionais direitos individuais, os chamados direitos sociais ou direitos de prestação, os quais dependem de prestações diretas e indiretas do Estado para serem usufruídos pelos cidadãos ${ }^{10}$, bem como dispuseram sobre a estruturação e organização econômica desses Estados.

No campo econômico, deixa de subsistir o Estado Liberal, da livre iniciativa, "que se traduz no direito de qualquer cidadão exercer atividade econômica livre de qualquer restrição" 11 , para dar espaço ao Estado Intervencionista, o qual participa da economia, "atua com o fito de se garantir o exercício racional das liberdades individuais"12 e cuja política "não visa ferir os postulados liberais, mas, tão somente, fazer com que o Estado coíba o exercício abusivo e pernicioso do liberalismo"13.

Para Vital Moreira, é introduzido "um novo modo do modo-de-ser das relações entre o económico e o jurídico-político, dentro da estrutura do estado moderno. Um novo modo-de-ser que exprime uma nova configuração da economia, da sociedade e do Estado, na sociedade capitalista contemporânea"14.

O modelo apontado, como assinala Gilberto Bercovici ${ }^{15}$, tem como precursora a Constituição alemã de 11 de agosto de 1919, frequentemente denominada "compromisso constitucional" ou "constituição programática" - esta também é conhecida simplesmente como Constituição de Weimar, a primeira carta a inserir, em uma secção especial, um conjunto de disposiçōes relativas à economia ${ }^{16}$ que teve repercussão instantânea e profunda, tanto na Europa como fora dela, graças às inovações introduzidas, ao submeter o individualismo a serviço da coletividade e proteger os direitos individuais.

Tão logo promulgada, a Constituição de Weimar foi duramente criticada pelos juristas, que classificaram as normas constitucionais atinentes aos direitos e

10 BERCOVICI, Gilberto. Constituição econômica e desenvolvimento: uma leitura a partir da Constituição de 1988. São Paulo: Malheiros, 2005. p. 11; idem. Constituição e estado de exceção permanente: atualidade de Weimar. Rio de Janeiro: Azougue, 2004a. p. 25.

11 FIGUEIREDO, Leonardo Vizeu. Liçôes de direito econômico. 3. ed. Rio de Janeiro: Forense, 2010. p. 43.

12 FIGUEIREDO, Leonardo Vizeu. Liçôes de direito econômico, p. 45.

13 FIGUEIREDO, Leonardo Vizeu. Liçôes de direito econômico, p. 45.

14 MOREIRA, Vital. Economia e Constituição. 2. ed. Lisboa: Coimbra, 1979. p. 9.

15 BERCOVICI, Gilberto. Constituição econômica e desenvolvimento: uma leitura a partir da Constituição de 1988, p. 27.

16 BERCOVICI, Gilberto. Constituição econômica e desenvolvimento: uma leitura a partir da Constituição de 1988, p. 78. 


\section{•• O orçamento como instrumento de intervenção no domínio econômico}

garantias como não jurídicas, assistemáticas e meras expressões políticas. Em suma, seus partidários, dentre os quais Carl Schmitt, defendiam os direitos fundamentais como seu conteúdo essencial, enquanto os opositores da República os viam como obstáculos desprezíveis, um resquício da burguesia liberal do século XIX, que deveria desaparecer ${ }^{17}$.

Considerada uma das primeiras Constituições econômicas, dispunha de um capítulo específico denominado "A vida econômica" e, assim como as demais constituições econômicas do século XX, não pretendia receber a estrutura econômica existente, mas alterá-la, o que lhe rendeu os ares de Constituição inovadora por positivar as tarefas a serem realizadas pelo Estado e pela sociedade no âmbito econômico, bem como por estabelecer a busca de determinados objetivos que também foram inseridos no texto constitucional ${ }^{18}$.

No Brasil, esta se instaura com a promulgação da Constituição de 16 de julho de 1934 , a qual inaugura o que se intitulou por terceira grande época ${ }^{19}$ e fora marcada por crises, golpes de Estado, insurreição, impedimentos, renúncia e, até mesmo, suicídio de Presidente e queda de governos republicanos ${ }^{20}$.

Aliado ao desejo de regular todas as instâncias do corpo social, com a Constituição de 1934 o Estado brasileiro promoveu uma intervenção maciça na economia

17 BERCOVICI, Gilberto. Constituição econômica e desenvolvimento: uma leitura a partir da Constituição de 1988, p. 27-30.

18 BERCOVICI, Gilberto. Constituição e estado de exceção permanente: atualidade de Weimar, p. 39.

19 De acordo com Paulo Bonavides, a primeira época está vinculada ao modelo constitucional francês e inglês do século XIX - estendendo-se de 1822 até 1889 -, em que o texto proposto introduziu em dois artigos um conceito de constitucionalidade, mantido depois pela Constituição de 1824, a qual teria sido, salvo notícia em contrário, a única Constituição Imperial no mundo que explicitamente perfilhou a repartição tetradimensional de poderes, ou seja, trocou o modelo de Montesquieu pelo de Benjamin Constant, acrescentando o Poder Moderador aos Poderes Executivo, Legislativo e Judiciário. A segunda época representaria uma ruptura ao modelo anterior e estaria atada ao modelo norte-americano. O novo Estado constitucional converter-se-ia, com a Constituição de 24 de fevereiro de 1891, em um Estado com plenitude formal das instituiçôes liberais, fundado, especialmente, no princípio republicano, na forma presidencial de governo, na forma federativa de Estado e no funcionamento de uma suprema corte, apta a decretar a inconstitucionalidade dos atos do poder. Por fim, a terceira época, que ainda hoje se vive, tem seu marco nos primeiros anos da década de 1930, com as Constituições de 1933-1934, na qual se percebe a presença de traços fundamentais presos ao constitucionalismo alemão do século XX. Para um estudo mais aprofundado, veja-se: BONAVIDES, Paulo. Curso de direito constitucional. 23. ed. São Paulo: Malheiros, 2008. p. 361-370; BONAVIDES, Paulo; ANDRADE, Antonio Paes de. História constitucional do Brasil. 5. ed. Rio de Janeiro: OAB, 2004.

20 BONAVIDES, Paulo, op. cit., p. 366. 
e, sob a influência da Constituição de Weimar, abrindo espaço para o tratamento da ordem econômica e social, contando, inclusive, com a reprodução do art. $151 \mathrm{da}$ Constituição alemã em uma de suas disposiçôes, a qual tratava da garantia da liberdade econômica apenas nos limites da "ordem econômica" e deveria "ser organizada conforme os princípios da justiça de modo a que possibilite a todos existência digna" ${ }^{21}$.

Além disso, a Constituição brasileira adotou uma nova estruturação para o federalismo nacional, o qual fora denominado cooperativo, de acordo com o art. 9०. No art. 10, fixou pela primeira vez a repartição das competências concorrentes e, nos arts. 140 e 177, tratou da cooperação entre os Entes Federados, ao dispor sobre o combate às endemias e às secas nas regióes constantemente atingidas.

Após 1934, todas as Constituiçôes brasileiras, exceto a de 1988, passaram a incluir um capítulo sobre a ordem econômica e social, para tratar da intervenção do Estado na economia e dos direitos trabalhistas.

A Constituição Federal de 1988, por sua vez, inovou ao incluir os direitos trabalhistas no capítulo que trata dos direitos sociais (arts. $6^{\circ}$ a 11 ) e inaugura o Título VII, especificamente para tratar da ordem econômica e financeira (arts. 170 a 192) ${ }^{22}$, denotando verdadeiro alargamento das obrigaçóes do Estado, que passou a atuar com maior dirigismo diante da necessidade de desenvolver e repensar sua relação com o mercado.

Como adverte Paulo Bonavides, é sobre uma terceira faixa que a Constituição inova profundamente. É sobre ela que "paira, todavia, o mais aceso dos debates e a mais acre das controvérsias: as regras nacionalistas sobre a ordem econômica, invectivas de xenofobia e desatualização com os rumos que, até mesmo das economias do mundo socialista, os ventos do progresso fazem soprar" ${ }^{23}$.

Expressamente reconhecida como uma Constituição econômica, dotada de um título específico, conforme mencionado, a Lei Maior brasileira é integralmente direcionada para a transformação das estruturas sociais. Ao sistematizar os dispositivos atinentes à atuação do Estado no domínio econômico, ainda que não se restrinjam a este capítulo do texto constitucional ${ }^{24}$, o Estado passou a figurar como

21 MOREIRA, Vital. Economia e Constituição, p. 81.

${ }^{22} \mathrm{Na}$ Constituição anterior, os direitos sociais, trabalhistas e econômico-financeiros eram tratados em um mesmo título (Da Ordem Econômica e Social).

23 BONAVIDES, Paulo; ANDRADE, Antonio Paes de. História constitucional do Brasil. 8. ed. Brasília: OAB, 2006. p. 490.

24 BERCOVICI, Gilberto. Constituição e Estado de exceção permanente: atualidade de Weimar, p. 30. 


\section{•• O orçamento como instrumento de intervenção no domínio econômico}

agente normativo e regulador da atividade econômica, em detrimento de uma suposta livre iniciativa, que nunca fora absoluta.

Como bem sintetiza José Afonso da Silva, "a atuação do Estado, assim, não é nada mais nada menos do que uma tentativa de pôr ordem na vida econômica e social, de arrumar a desordem que provinha do Liberalismo" 25 .

Resta demonstrado que o Estado, de um modo ou de outro, sempre interveio na economia e na sociedade. Com os propósitos de pôr-se em ordem na vida econômica e na social, o povo lhe dotou de força e poder suficiente para impor a realização de determinados comportamentos, os quais nem sempre se restringem aos limites legais e até mesmo morais. Em suma, e como se propõe demonstrar nesta dissertação, o Estado - ou aqueles que o governam - vale-se de outros instrumentos, como o orçamento público, para conduzir a sociedade e a economia.

\subsection{CAMPO DE ATUAÇÃO PRIVADO E CAMPO DE ATUAÇÃO RESERVADO À ADMINISTRAÇÃO PÚBLICA: PRINCIPAIS DISTINÇÕES}

Conforme observado, a Constituição Federal brasileira atual, influenciada pela Constituição de Weimar, e também pela Constituição mexicana de 1917, diante das transformações históricas apontadas, acabou por alargar de maneira significativa as obrigações do Estado, que, com isso, deixa de figurar como mero agente normativo e regulador da atividade econômica e começa a participar e atuar diretamente na economia, em áreas até então reservadas unicamente ao desenvolvimento dos negócios privados.

O Estado, desde os primórdios do pensamento liberal, incumbia-se da produção dos bens coletivos - por exemplo, exército, polícia, iluminação pública -, mas, sobretudo depois da Primeira Guerra Mundial, passa a se responsabilizar diretamente pela prestação de determinados bens que, ainda que qualificados como "públicos" e "sociais", poderiam ser produzidos pela iniciativa privada e foram retirados do mercado, deixando a intervenção do Estado na economia de limitar-se à produção dos bens coletivos ${ }^{26}$.

Diante disso, surge a necessidade de se fazer a distinção entre esses campos de atuação, isto é, entre aquele atinente à iniciativa privada e o adstrito às atividades

25 SILVA, José Afonso da. Comentário contextual à Constituição. 6. ed. São Paulo: Malheiros, 2009. p. 705.

26 MONCADA, Luís S. Cabral de. Direito económico. 5. ed. revista e actualizada. Lisboa: Coimbra, 2007. p. 435-436. 
estatais, a fim de possibilitar a compreensão do que se deve entender por dominio econômico ou atividade econômica e, por conseguinte, tratar das formas de atuação do Estado em relação ao processo econômico.

Para tanto, tomar-se-á como ponto de partida a análise do texto constitucional, em particular das normas de conteúdo econômico e social, e daquelas que tratam de modo específico das atividades econômicas, previstas, respectivamente, no art. 21, incs. XI e XII, e nos arts. 173, 174 e 175, a fim de que se possam traçar as principais diferenças entre os campos de atuação privado e aquele atribuído ao Poder Público.

A atividade econômica, oriunda do regime capitalista, como é o brasileiro, prosperou no regime da livre iniciativa, consistente em um direito fundamental enquanto exercido com o propósito de atender à realização da justiça social, da valorização do trabalho e do desenvolvimento nacional ${ }^{27}$.

A Constituição Federal contempla uma ordem econômica fundada na valorização do trabalho humano e na livre iniciativa, e tem como propósito assegurar a todos uma existência digna e em consonância com a justiça social (art. 170). Em razão disso, a Lei Maior brasileira estabelece que a exploração direta de atividade econômica pelo Estado só será permitida quando necessária aos imperativos da segurança nacional ou para atender a relevante interesse coletivo (art. 173).

O texto constitucional denota que à iniciativa privada é conferido o privilégio de atuar no plano da atividade econômica, cabendo ao Poder Público, como exceção, desenvolver apenas as atividades que a ordem pública expressamente lhe atribui, em respeito ao princípio da legalidade, o qual, de acordo com Celso Antônio Bandeira de Mello, resulta "da submissão do Estado à lei" 28 .

Extensão da teoria da soberania popular e da representação parlamentar, qualquer "atentado" à liberdade econômica e à propriedade somente poderia ser consumado por intermédio de uma lei. Assume, assim, o princípio da legalidade sua dupla face, como supremacia e reserva da lei, pois "corolário da separação dos poderes, importando exclusivamente a oposição de um limite à atuação do Estado"29.

27 SILVA, José Afonso da. Curso de direito constitucional positivo. 19. ed. São Paulo: Malheiros, 2001. p. 779.

28 MELLO, Celso Antônio Bandeira de. Curso de direito administrativo. 28. ed. São Paulo: Malheiros, 2011. p. 100.

29 GRAU, Eros Roberto. O direito posto e o direito pressuposto. 8. ed. São Paulo: Malheiros, 2011. p. 171. 
O Estado, diante do princípio da legalidade, estaria proibido de fazer o que a Constituição ou as leis explicitamente não autorizam ${ }^{30}$ e só estará autorizado a desenvolver qualquer atividade econômica quando esta se mostrar necessária à manutenção da segurança nacional ou de relevante interesse coletivo ${ }^{31}$.

Ainda que as considerações apresentadas não sejam pacíficas na doutrina, Maria Sylvia Zanella di Pietro ${ }^{32}$, ao tratar das alterações introduzidas no Direito Administrativo após a Constituição de 1988, e em face da adoção dos princípios do Estado Democrático de Direito ou da inspiração do neoliberalismo e da globalização ${ }^{33}$, afirma ter havido, dentre outros, o alargamento do princípio da legalidade, o qual teria deixado de se restringir apenas à lei, para abranger, também, princípios e valores, e com isso impor maior limitação à discricionariedade da Administração Pública, sujeitando-a ainda mais ao controle judicial.

A propósito, Odete Medauar ${ }^{34}$ esclarece que na passagem do Estado Liberal para o Estado Constitucional as leis já não mais persistiam intactas, tendo deixado o princípio da legalidade de ser compreendido como mera vinculação positiva à lei formal para conter também preceitos valorativos e éticos, sujeitando a atividade administrativa à observância dos preceitos fundamentais insculpidos na Constituição, como verdadeiros vetores indicativos e interpretativos à realização da atividade administrativa.

Tem-se que, por um lado, o princípio da legalidade inflige à Administração a obrigatoriedade de adotar, em sua atuação, um procedimento conforme a lei, obrigação essa consistente na imposição de aplicá-las e na proibição de delas se desviar

30 A Constituição Federal brasileira (art. 21) indica de modo expresso alguns serviços que, obrigatoriamente, constituem serviços públicos, atribuindo ao poder público sua exploração, dentre os quais se destacam: o serviço postal e o correio aéreo nacional (inc. X); os serviços de telecomunicações (inc. XI); e a navegação aérea, aeroespacial e a infraestrutura portuária (inc. XII).

31 FERREIRA FILHO, Manoel Gonçalves. Curso de direito constitucional. 38. ed. revista e atualizada São Paulo: Saraiva, 2012. p. 394-395.

32 DI PIETRO, Maria Sylvia Zanella. Direito administrativo. 26. ed. São Paulo: Atlas, 2013. p. 27-29.

33 A respeito da influência da globalização sobre o direito, em especial o Direito Administrativo, vejam-se SUNDFELD, Carlos Ari; VIEIRA, Oscar Vilhena. Direito global. São Paulo: Max Limond, 1999. p. 157-168; e GUERRA, Sérgio. Discricionariedade administrativa - limitações da vinculação legalitária e propostas pós-positivistas. In: ARAGÃO, Alexandre Santos de; MARQUES NETO, Floriano de Azevedo (Coord.). Direito administrativo e seus novos paradigmas. Belo Horizonte: Fórum, 2008. p. 205-240.

34 MEDAUAR, Odete. O direito administrativo em evolução. 2. ed. São Paulo: RT, 2003. p. 146. 
(vinculação à lei em sentido estrito) e, por outro, significa que a Administração não pode violar o primado e a reserva de lei (vinculação à lei em sentido amplo).

De todo modo, e ainda que a doutrina não compartilhe do mesmo entendimento no tocante à atual abrangência do princípio da legalidade, verifica-se que, em qualquer uma das hipóteses apontadas - segurança nacional ou relevante interesse coletivo -, nem todas as atividades conferidas pela Constituição ao Poder Público lhe são reservadas, ou, em outras palavras, nem todas lhe são atribuídas com exclusividade.

É o caso, por exemplo, da educação, da saúde e dos serviços de previdência e de assistência social, que constituem deveres do Estado (arts. 196, 199, caput, 205 e 209 da CF/1988), embora também possam ser exploradas pela iniciativa privada.

Distintas do serviço público, certas atividades privadas entregues à livre iniciativa, por força de lei, dependem de prévia autorização dos órgãos públicos (art. 170, parágrafo único, da CF/1988), ou seja, "de uma prévia manifestação administrativa, destinada a verificar, no exercício de 'polícia administrativa', se será desempenhada dentro das condiçôes compatíveis com o interesse coletivo" 35 .

Logo, o campo de atuação conferido à iniciativa privada é constituído pelas atividades próprias dos particulares, as quais, por sua vez, dividem-se em duas categorias $^{36}$ : (i) aquelas conferidas expressamente aos indivíduos pela Constituição como um direito subjetivo, dentre as quais citem-se o exercício do trabalho, ofício ou profissão (art. 5o, XIII, da CF/1988) e a exploração de atividade econômica (art. 170, parágrafo único, da CF/1988); e (ii) aquelas que, não tendo sido atribuídas com exclusividade ao Estado, lhes são facultadas, como as atividades de educação e saúde (arts. 199, caput, e 209 da CF/1988), anteriormente mencionadas.

Excluem-se do campo privado, portanto, as atividades que, segundo a Constituição Federal, são reservadas exclusivamente ao Estado e por este devem obrigatoriamente ser prestadas, não podendo ser transferidas por concessão, permissão ou autorização ${ }^{37}$.

Para muitos autores é com base na compreensão do que se entende por serviço público que se separa o campo de atuação do Estado do campo atribuído aos particulares, compondo este último o que se denomina atividade econômica ou, simplesmente, domínio econômico. No entanto, mostra-se difícil a tarefa de traçar uma

35 MELLO, Celso Antônio Bandeira de. Curso de direito administrativo, p. 693.

36 SUNDFELD, Carlos Ari. Fundamentos de direito público. 3. ed. São Paulo: Malheiros, 1997. p. 75.

37 Trata-se das hipóteses de monopólio da União constantes do art. 177 da CF/1988. 


\section{•• O orçamento como instrumento de intervenção no domínio econômico}

distinção entre ambas e apresentar uma noção exata do que se possa compreender por serviço público, pois as mudanças no modelo de Estado provocaram alteraçóes significativas em sua definição em cada sociedade e em cada período, como assinala Hely Lopes Meirelles ${ }^{38}$ : "Realmente, o conceito de serviço público é variável e flutua ao sabor das necessidades e contingências políticas, econômicas, sociais e culturais de cada comunidade, em cada momento histórico, como acentuam os modernos publicistas".

Além disso, Dinorá Grotti ${ }^{39}$, dentre outros, cita como sendo Jean-Jacques Rousseau o primeiro a se valer da expressão "serviço público" para significar qualquer atividade estatal abrangendo dois aspectos, in verbis:

(...) de um lado, trata-se de atividades destinadas ao serviço público, isto é, ações através das quais se assegura aos cidadãos a satisfação de uma necessidade sentida coletivamente, sem que cada um tenha de atendê-la pessoalmente; de outro, concebe-se como uma atividade estatal que sucede ao serviço do Rei, porque se operou uma substituição na titularidade da soberania.

De fato, Rousseau assim emprega a expressão, tanto quanto adverte que "a partir do momento em que o serviço público deixa de ser a principal preocupação dos cidadãos e em que eles preferem servir-se do seu bolso a servir-se da sua pessoa, o Estado já está à beira da ruína” ${ }^{30}$.

Foi durante o movimento da primeira industrialização, compreendido pelo período entre o término do século XIX e o final do século XX, que surgiu a Teoria do Serviço Público, então desenvolvida pelo Conselho de Estado e pelo Tribunal de Conflitos Francês, cujas primeiras noções foram esboçadas por Maurice Hauriou ${ }^{41}$ e, posteriormente, lapidadas por Léon Duguit, para quem todo problema da atividade do Estado se resolvia por uma antítese: mandar ou servir ${ }^{42}$. Assim é que Gaston Jèze, discípulo de Duguit, manifestou-se:

38 MEIRELLES, Hely Lopes. Direito administrativo brasileiro. 28. ed. São Paulo: Malheiros, 2003. p. 319.

39 GROTTI, Dinorá Adelaide Museti. Teoria dos serviços públicos e sua transformação. In: SUNDFELD, Carlos Ari. Direito administrativo econômico. 3. tiragem. São Paulo: Malheiros, 2006. p. 40.

40 ROUSSEAU, Jean-Jacques. Do contrato social. Tradução de Eduardo Brandão; organização e introdução de Maurice Cranston. São Paulo: Penguin Classics/Companhia das Letras, 2011. p. 149.

41 RIVERO, Jean. Hauriou et l'avènement de la notion de service public. In: MESTRE, Melanges. L'evolution du driot public: études en l'honneur d'Achilles Mestre. Paris: Sirey, 1956. p. 461 e ss.

42 DUGUIT, Léon. Les transformations du droit public. Paris: A. Colin, 1913. p. X. 
La idea de servicio público se halla íntimamente vinculada con la del procedimiento de derecho público.

Decir que, en determinada hipótesis, existe servicio público, equivale a afirmar que los agentes públicos, para dar satisfacción regular y continua a cierta categoría de necesidades de interés general, pueden aplicar los procedimientos del derecho público, es decir, un régimen jurídico especial, y que las leyes y reglamentos pueden modificar en cualquier momento la organización del servicio público, sin que pueda oponerse a ello ningún obstáculo insuperable de orden jurídico ${ }^{43}$. (Grifo do original.)

Para Gaston Jèze ${ }^{44}$, a Administração Pública deve satisfazer uma série de necessidades de interesse geral, dentre as quais algumas devem ser satisfeitas de forma exclusiva e, outras, em conjunto com os particulares, denotando a existência de dois procedimentos para sua realização - o de direito privado e o de serviço público -, segundo os quais:

El procedimiento del derecho privado supone, esencialmente, la igualdad de los intereses particulares en conflicto. Ningún interés privado, por legítimo y digno de estímulo que sea, puede prevalecer sobre otro interés privado, por más egoísta que fuese este último. (...).

Por lo contrario el procedimiento del derecho público tiene su fundamento en la idea de desigualdad de los intereses en conflicto: el interés público debe prevalecer sobre el interés privado. Éste es el principio dominante, y no es necesario que la ley se haya referido a él, expresamente, para tal o cual interés público. (Grifo do original.)

Diante da teoria desenvolvida pelo jurista francês em comento, duas noções de serviço público surgiram: uma ampla, indicando todo o conjunto de fins sociais a serem garantidos pela Administração Pública; e outra estrita, segundo a qual, o Estado deveria assumir, de forma direta ou controlada, a realização de certas necessidades sociais sob a veste de um regime exorbitante de direito comum.

Em suma, nessa época, a noção de serviço público detinha alguns contornos bastante definidos: um elemento subjetivo, caracterizado pelo fato de ter de ser prestado apenas pelo Estado; outro objetivo, pois tinha por objeto a satisfação de necessidades coletivas; e um terceiro elemento, formal, que o sujeitava a um regime jurídico exclusivamente de direito público.

43 JĖZE, Gaston. Principios generales del derecho administrativo. Traduzido para o espanhol por Julio N. San Millán Almagro. Buenos Aires: Depalma, 1949. v. II, t. I, p. 4. Tradução da 3. ed. francesa: Les principes généraux du droit administratif.

44 JĖZE, Gaston. Principios generales del derecho administrativo. Traduzido para o espanhol por Julio N. San Millán Almagro. Buenos Aires: Depalma, 1949. v. II, t. I, p. 5-6. Tradução da 3. ed. francesa: Les principes généraux du droit administratif. 
Reconhecia-se a existência de um serviço público quando as autoridades de um país, em determinada época, decidiam satisfazer as necessidades de interesse geral valendo-se do sistema público ${ }^{45}$.

Nada distante da conclusão enunciada por Bandeira de $\mathrm{Mello}^{46}$, segundo o qual a noção de serviço público há de se compor, necessariamente, de dois substratos: um material, consistente na prestação de utilidade ou comodidade fruível singularmente pelos administrados e, outro, formal, que lhe confere justamente caráter de noção jurídica, consistente em um específico regime de Direito Público.

Ocorre que ao longo do tempo e inicialmente nos países europeus, o modelo de financiamento dos serviços públicos pelo orçamento do Estado se revelou impraticável. As despesas públicas aumentaram vertiginosamente e o Estado perde eficiência na prestação dos serviços públicos, deixando de funcionar o propósito redistributivo, o que impunha, especificamente na Europa, a revisão do "Estado Social", como se tem verificado desde a década de $1980^{47}$.

No Brasil, nas últimas décadas, teve início o que se intitulou "Reforma do Estado". Iniciada mais precisamente em meados da década de 1990, seus objetivos eram marcados pelos propósitos de reestruturação e reformulação da forma de intervenção do Estado no domínio econômico, os quais causaram reflexos diretos na noção de serviço público, então construído basicamente sob o contexto do Estado Social.

Com a adoção de diversas medidas visando à reformulação do aparelho estatal - a qual é marcada no plano constitucional pela introdução da Emenda Constitucional n. 19/1998 -, dentre as quais notadamente as que tinham por objetivo o encolhimento da máquina estatal, restou instituído um amplo programa de privatizaçōes tendentes a atribuir à iniciativa privada a prestação de serviços públicos. $\mathrm{O}$ resultado foi o nascimento das agências reguladoras que ainda hoje detêm como principal incumbência fiscalizar as atividades deixadas a cargo do setor privado ${ }^{48}$.

Além disso, tinha-se como propósito instituir a chamada "administração gerencial”’49, com a finalidade de atribuir maior eficiência na prestação dos serviços

\footnotetext{
JĖZE, Gaston. Principios generales del derecho administrativo, p. 19.

46 MELLO, Celso Antônio Bandeira de. Curso de direito administrativo, p. 682.

47 MONCADA, Luís S. Cabral de. Direito económico, p. 437.

48 GROTTI, Dinorá Adelaide Museti. O serviço público e a Constituição Brasileira de 1988. São Paulo: Malheiros, 2003. p. 141.

49 De acordo com Luiz Carlos Bresser-Pereira, foi no Governo Fernando Henrique Cardoso, diante de um quadro desfavorável e negativo cuja origem deu-se no Governo Collor, que se
} 
e, por consequência, obter resultados satisfatórios, inserindo na Administração Pública mecanismos da iniciativa privada ${ }^{50}$.

Esse conjunto de medidas afetou a concepção clássica de serviços públicos trazida do Direito francês, considerada importante, por um lado, por separar a competência da jurisdição administrativa da competência da justiça comum e, por outro, por servir como critério de definição do próprio Direito Administrativo ${ }^{51}$, conforme salientado.

Alexandre Aragão ${ }^{52}$ esclarece que a noção de serviço público sempre fora marcada por sucessivas crises, destacando-se, dentre elas, duas. A primeira, ocorrida em meados do século XX, com o aumento da intervenção estatal na economia, em que se verifica o incremento da intensidade de intervenção regulatória sobre as atividades econômicas privadas e mediante o exercício direto, pelo Estado, de uma série de atividades econômicas, comerciais e industriais. A segunda, iniciada na década de 1980, em que, ao contrário da primeira, foi determinante para o avanço da esfera pública sobre a privada, com a devolução ao mercado de uma série de atividades que dele haviam sido retiradas.

De qualquer modo, e como bem aponta o autor ${ }^{53}$ precitado,

(...) o serviço público, ainda que viva momentos de expansão e de retração, não vai deixar de existir. Poderá variar a sua titularidade, seu objeto, seu regime jurídico, e até as formas de sua prestação, dando maior protagonismo aos operadores privados. Todavia, o substrato público do instituto sempre se manterá.

Diante das consideraçôes tecidas e ainda que seja tarefa difícil condensar os elementos que identifiquem o conteúdo da expressão serviço público, mostra-se de

iniciou a mencionada reforma gerencial ou reforma da gestão pública de 1995. Principal protagonista dessa reforma, coube a Bresser Pereira e sua equipe idealizá-la e implementá-la, tendo como causa central o aumento do tamanho do Estado e sua transformação em Estado democrático e social, que o obrigava a se tornar mais eficiente. É o que se pretendeu com a reforma constitucional efetivada com a edição da Emenda Constitucional n. 19/1998, cuja grande parte das mudanças institucionais foram de caráter infraconstitucional (BRESSER-PEREIRA, Luiz Carlos. Burocracia pública e reforma gerencial. Revista do Serviço Público, Brasília, p. 29-48, edição especial de 2007).

50 BERCOVICI, Gilberto. Constituição econômica e desenvolvimento: uma leitura a partir da Constituição de 1988, p. 82.

51 DI PIETRO, Maria Sylvia Zanella. Direito administrativo, p. 99-100.

52 ARAGÃO, Alexandre Santos de. O serviço público e as suas crises. In: ARAGÃO, Alexandre Santos de; MARQUES NETO, Floriano de Azevedo (Coord.). Direito administrativo e seus novos paradigmas. Belo Horizonte: Fórum, 2008. p. 421-440.

53 SARASOLA GORRITI, Silbia. La concesión de servicios públicos municipales: estudio especial de las potestades de intervención. Oñati: IVAP, 2003. p. 22-23. 


\section{•• O orçamento como instrumento de intervenção no domínio econômico}

relevância consignar alguns significados propostos pela doutrina atual, dentre os quais este estudo se coaduna com o sentido empregado por Celso Antônio Bandeira de Mello ${ }^{54}$, conforme colacionado a seguir:

Serviço público é toda atividade de oferecimento de utilidade ou comodidade material destinada à satisfação da coletividade em geral, mas fruível singularmente pelos administrados, que o Estado assume como pertinente a seus deveres e presta por si mesmo ou por quem lhe faça as vezes, sob um regime de Direito Público - portanto, consagrador de prerrogativas de supremacia e de restrições especiais -, instituído em favor dos interesses definidos como públicos no sistema normativo.

Nessa mesma linha de raciocínio, Odete Medauar ${ }^{55}$ diz que serviço público está atrelado às atividades realizadas no âmbito das atribuiçóes da Administração e, assim, inserido no Executivo, consistindo em uma atividade "prestacional, em que o poder público propicia algo necessário à vida coletiva, como, por exemplo, água, energia elétrica, transporte urbano", não se inserindo nesse conceito as atividades-meio, como, por exemplo, arrecadação de tributos, serviços de arquivo, limpeza e vigilância de repartições etc.

Hely Lopes Meirelles, por sua vez, entende serviço público como "todo aquele prestado pela Administração ou por seus delegados, sob normas e controles estatais, para satisfazer necessidades essenciais ou secundárias da coletividade ou simples conveniências do Estado" 56 .

Ainda, de acordo com ponderação de Luís S. Cabral de Moncada ${ }^{57}$ :

Claro está que o serviço público é sempre um serviço de interesse geral, sendo este elemento essencial da respectiva noção. Apenas sucede que o serviço público pode ser prestado por entidades públicas e temos o serviço público em sentido orgânico ou subjectivo e por outras entidades autónomas e privadas e temos o serviço público em sentido funcional e objectivo.

Eros Grau ${ }^{58}$ vai além e, valendo-se da expressão de maneira mais ampla, afirma que a noção de serviço público também há de ser construída sobre as ideias de coesão e de interdependência social. Diz ainda o autor, que essa atividade deve ser prestada à sociedade pelo Estado - ou por outra pessoa administrativa, direta ou indiretamente -, assumindo caráter existencial e constituindo uma atividade explícita ou supostamente definida pela Constituição como indispensável, "ou, em

54 MELLO, Celso Antônio Bandeira de. Curso de direito administrativo, p. 679.

55 MEDAUAR, Odete. Direito administrativo moderno. 16. ed. São Paulo: RT, 2012. p. 347.

56 MEDAUAR, Odete. Direito administrativo moderno, p. 319.

57 MONCADA, Luís S. Cabral de. Direito económico, p. 439.

58 GRAU, Eros Roberto. A ordem econômica na Constituição de 1988, p. 134. 
outros termos, (...) como serviço existencial relativamente à sociedade em determinado momento histórico" 59 .

Nota-se que os serviços públicos estão inseridos no campo de alçada do Estado, contrapondo-se ao o que a Constituição Federal chamou de "domínio econômico", ou seja, ao campo das atividades dos particulares, que, na definição de Lúcia Valle Figueiredo ${ }^{60}$, "compreende o conjunto de atividades desenvolvidas pela livre iniciativa. Portanto, constitui-se no centro onde gravita a possibilidade de se fazer riqueza, ou seja, a atividade econômica”.

Com o propósito de melhor especificar o que se deve compreender sobre cada um dos termos jurídicos apresentados, esclarece Eros Grau que, do gênero atividade econômica, depreende-se duas espécies: (i) o serviço público; e (ii) a atividade econômi$c a$. E, no que toca às atividades econômicas propriamente ditas (espécie), distinguem-se estas em atividades econômicas em sentido amplo e em sentido estrito ${ }^{61}$.

Nas palavras desse autor ${ }^{62}$ :

Por certo que, no art. 173 e seu $\$ 1^{\circ}$, a expressão conota atividade econômica em sentido estrito. $\mathrm{O}$ art. 173, caput, enuncia as hipóteses nas quais é permitida ao Estado a exploração direta de atividade econômica. Trata-se, aqui, de atuação do Estado - isto é, da União, do Estado-membro e do Município - como agente econômico, em área da titularidade do setor privado. Insista-se em que atividade econômica em sentido amplo é território dividido em dois campos: o do serviço público e o da atividade econômica em sentido estrito. As hipóteses indicadas no art. 173 do texto constitucional são aquelas nas quais é permitida a atuação da União, dos Estados-membros e dos Municípios neste segundo campo.

Para Eros Grau, portanto, “o Estado não pratica intervenção quando presta serviço público ou regula a prestação de serviço público. Atua, no caso, em área de sua própria titularidade, na esfera pública"63.

Como assevera Bandeira de Mello ${ }^{64}$, a Constituição Federal estabeleceu "uma grande divisão: de um lado, atividades que são da alçada dos particulares - as

59 GRAU, Eros Roberto. A ordem econômica na Constituição de 1988, p. 135.

60 FIGUEIREDO, Lúcia Valle. Reflexões sobre a intervenção do estado no domínio econômico e as contribuiçōes interventivas. In: MACHADO, Hugo de Brito (Coord.). As contribuiçôes no sistema tributário brasileiro. São Paulo: Dialética/Fortaleza: Instituto Cearense de Estudos Tributários, 2003. p. 397.

61 GRAU, Eros Roberto. A ordem econômica na Constituição de 1988, p. 101-102.

62 GRAU, Eros Roberto. A ordem econômica na Constituição de 1988, p. 103.

63 GRAU, Eros Roberto. A ordem econômica na Constituição de 1988, p. 91.

64 MELLO, Celso Antônio Bandeira de. Curso de direito administrativo, p. 801. 


\section{•• O orçamento como instrumento de intervenção no domínio econômico}

econômicas; e, de outro, atividades que são de alçada do Estado, logo, implicitamente qualificadas como juridicamente não econômicas - os serviços públicos".

Extrai-se do exposto, que a noção de atividade econômica (em seu sentido estrito) é construída com base na eliminação das atividades atribuídas exclusivamente ao Estado (parcela do gênero atividade econômica), segundo a qual, o que não for serviço público (art. 175 da CF/1988) e estiver fora das demais preocupaçōes estatais será atividade econômica ${ }^{65}$. Dito de outro modo:

O que prevalece é a vontade soberana do Estado, qualificando o serviço como público ou de utilidade pública, para sua prestação direta ou indireta, pois serviços há que, por natureza, são privativos do Poder Público e só por seus órgãos devem ser executados, e outros são comuns ao Estado e aos particulares, podendo ser realizados por aqueles e estes. Daí essa gama infindável de serviços que ora estão exclusivamente com o Estado, ora com o Estado e particulares e ora unicamente com particulares ${ }^{66}$.

Em síntese, o campo de atuação conferido à iniciativa privada, ou seja, o domínio econômico, é constituído pelas atividades conferidas expressamente aos indivíduos pela Constituição como um direito subjetivo e por aquelas que, não tendo sido atribuídas com exclusividade ao Estado, lhes é facultada a exploração.

\subsection{OS OBJETIVOS DA INTERVENÇÃO EXERCIDA PELO ESTADO SOBRE O DOMÍNIO ECONÔMICO}

Como já demonstrado neste estudo, o insucesso dos modelos intervencionistas social e socialista impôs ao Estado a necessidade de repensar as formas pelas quais poderia interferir no processo de geração de riquezas, tanto quanto na realização de políticas públicas de inclusão social e de repartição de rendas. Com isso, o Estado viu-se obrigado a abandonar a planificação econômica sem, todavia, voltar ao liberalismo econômico idealizado por Adam Smith.

Ainda que a Constituição brasileira (arts. 173 e 174) tenha assegurado à iniciativa privada a preferência pela exploração da atividade econômica, e que alguns propalem, como Hely Lopes Meirelles ${ }^{67}$, que não mais se admitiria nenhuma intervenção do Estado na economia, mas apenas sua atuação supletiva, verifica-se que o

65 NASCIMENTO, Tupinambá Miguel Castro do. Comentários à Constituição Federal: ordem econômica e financeira. Porto Alegre: Livraria do Advogado, 1997. p. 45.

66 MEIRELLES, Hely Lopes. Direito administrativo brasileiro, p. 614.

67 MEIRELLES, Hely Lopes. Direito administrativo brasileiro, p. 545-546. 
sistema capitalista nacional, como pontua Celso Bastos, encontra-se "temperado por graus diversos de intervenção do Estado"68.

A bem da verdade, e como já manifestado, o Estado nunca deixou de intervir no domínio econômico, ora o fazendo mais, ora menos, sendo certo que o texto constitucional vigente consagra uma economia de mercado descentralizada e sujeita à forte atuação do Estado ${ }^{69}$.

Ao distinguir os campos de atuação pública e privada, pode-se dizer que ao intervir no domínio econômico, ou seja, no campo de atividade econômica em sentido estrito ${ }^{70}$, o Estado o faz para orientar a ação dos sujeitos econômicos, influenciando-os legislativa e administrativamente com o propósito de alcançar determinados fins.

De acordo com Fábio Nusdeo ${ }^{71}$, duas seriam as motivações estatais para a intervenção: uma negativa e outra positiva. A primeira, dita negativa, decorreria de "uma ação não contra o mercado, mas, pelo contrário, em harmonia com ele, suprimindo-lhe as deficiências, sem lhe tolher as condiçôes de funcionamento". A segunda, positiva, seria oriunda da "ordem decorrente da colocação, agora sim, consciente, de objetivos da política econômica no seu desempenho".

$\mathrm{Na}$ motivação negativa protege-se a livre iniciativa e as atividades econômicas desempenhadas pelos particulares, cabendo ao Estado tão somente corrigir distorções, ao passo que, na segunda, o Estado busca estabelecer objetivos para o mercado, ações diretivas e indutivas aos particulares para que esse mercado se aproxime ao máximo daquele desejado pelo Estado.

Corporificado e instrumentalizado pelo ordenamento jurídico, compete ao Estado atuar de acordo com os limites e parâmetros definidos na Constituição brasileira. A propósito, Celso Bastos ${ }^{72}$ explica que "o direito é essencial, necessário e inevitável ao Estado, pois é ele o conteúdo mínimo garantidor de sua essência”.

O poder que o Estado detém, de orientar e regular as relações econômicas, é determinado pelo texto constitucional e com o objetivo de atingir os fins almejados

68 BASTOS, Celso Ribeiro; MARTINS, Ives Gandra da Silva. Comentários à Constituição do Brasil: promulgada em 5 de outubro de 1988. São Paulo: Saraiva, 1988. v. 7, p. 12.

69 MORAES, Alexandre de. Direito constitucional. 29. ed. São Paulo: Atlas, 2013. p. 832.

70 MEIRELLES, Hely Lopes, op. cit., p. 91-92.

71 NUSDEO, Fábio. Curso de economia: introdução ao direito econômico. 6. ed. São Paulo: RT, 2010. p. 167-169.

72 BASTOS, Celso Ribeiro. Curso de direito constitucional. 22. ed. revista e atualizada por Samantha Meyer-Pflug. São Paulo: Malheiros, 2010. p. 60. 


\section{•• O orçamento como instrumento de intervenção no domínio econômico}

pela sociedade, dentre os quais, aqueles estabelecidos no preâmbulo e nos arts. $3^{\circ} \mathrm{e}$ 170, dentre outros, da Constituição Federal, e sobre os quais não compete, aqui, tecer mais considerações.

Por isso se disse antes que o Estado intervencionista brasileiro passou a participar da economia e a atuar com a finalidade de garantir o exercício racional das liberdades individuais com o aparente propósito de coibir abusos, ainda que o texto constitucional (art. 170) tenha assegurado a todos o livre exercício de qualquer atividade econômica.

Sua transformação deu-se quando as ordens econômicas precedentes começam a instrumentar a implementação de políticas públicas, ou seja, "no instante em que a ordem econômica - parcela da ordem jurídica -, já instalada no nível constitucional, passa a predicar o aprimoramento da ordem econômica (mundo do ser), visando a sua preservação" 73 .

Como afirma Fernando Facury Scaff ${ }^{74}$, o Estado, ao intervir no domínio econômico, cumpre não apenas o papel socializante, mas, ao contrário, também:

(...) o papel de mitigar os conflitos do Estado Liberal, através da atenuação de suas características - a liberdade contratual e a propriedade privada dos meios de produção -, a fim de que haja separação entre os trabalhadores e os meios de produção.

Pode-se dizer, com isso, que o Estado tem de intervir na economia não apenas para proteger os meios de produção - obrigação atribuída por muitos à classe dominante -, mas, também, para proteger a sociedade dos impactos destrutivos do capitalismo que, sujeito a períodos de recessão ou depressivos, deve procurar minimizá-los, mesmo naquelas situações em que seja impossível evitá-los.

Considerados os propósitos mencionados, o Estado se faz presente na atividade econômica de duas formas: (i) como agente econômico e (ii) como agente normativo e regulador da economia. Intervém, assim, na economia, porque há interesse privado, não diretamente na assunção daquela atividade, mas de que sua efetivação seja levada a termo pelo Estado ${ }^{75}$.

Ao exercer o poder de intervir no domínio econômico, a Constituição Federal brasileira (art. 174) determina que o Estado, na qualidade de agente normativo e regulador da atividade econômica, assim o faça na forma e nos limites legais, mas

73 GRAU, Eros Roberto. A ordem econômica na Constituição de 1988, p. 72.

74 SCAFF, Fernando Facury. Responsabilidade civil do estado intervencionista. 2. ed. São Paulo: Renovar, 2001. p. 91.

75 SCAFF, Fernando Facury. Responsabilidade civil do estado intervencionista, p. 97. 
também com o propósito de realizar as funções de fiscalização, incentivo e planejamento, sendo este último determinante (obrigatório) para o setor público e indicativo para o setor privado.

A interferência do Estado no domínio econômico deve ser feita, portanto, com respeito aos ditames legais e tão somente com o propósito de normatizar e regular a atividade econômica, fiscalizando-a e, principalmente, incentivando sua realização a fim de propiciar o desenvolvimento do país, não podendo impor aos particulares "nem mesmo o atendimento às diretrizes ou intenções pretendidas, mas apenas incentivar, atrair os particulares, mediante planejamento indicativo" 76 .

\subsection{MODOS DE INTERVENÇÃO}

Demonstradas as razões que impulsionaram os Estados a intervirem na economia, torna-se necessário elencar os principais modos de intervenção sobre o domínio econômico, ainda que não haja unanimidade na doutrina sobre a adoção de um critério específico.

Verificou-se, aqui, que os serviços públicos constituem uma atividade explícita definida na Constituição Federal brasileira, existencial e indispensável à sociedade, inserida no campo de atuação do Estado ${ }^{77}$. Assim, quando os realiza não há, portanto, que se falar em intervenção, pois o Estado atua em área de sua própria titularidade, ou seja, na esfera pública ${ }^{78}$.

Em face da variedade de propostas de classificações, e diante das distinções traçadas entre atividade econômica em sentido amplo e em sentido estrito, concentrando-se nesta última o objeto do presente estudo, procurar-se-á sintetizar as mais citadas tanto pela doutrina nacional como pela estrangeira. Em seguida, adotar-se-á um critério específico com o propósito de, posteriormente, identificar qual é efetivamente o papel que o orçamento público assume perante o domínio econômico.

A propósito, como demonstrado por Genaro Carrió, as classificações "no son ni verdaderas ni falsas, son serviciales o inútiles; sus vantajas o desventajas están supeditadas al interés que guía e quien las formula"79.

76 MELLO, Celso Antônio Bandeira de. Curso de direito administrativo, p. 804.

77 SILVA, José Afonso da. Curso de direito constitucional positivo, p. 779.

78 GRAU, Eros Roberto. A ordem econômica na Constituição de 1988, p. 91.

79 CARRIÓ, Genaro. Notas sobre derecho y lenguaje. 4. ed. Buenos Aires: Abeledo-Perrot, 1990. p. 99. 
A despeito de todas as classificações se mostrarem parecidas ou similares, para que se possa operacionalizar a presente publicação faz-se necessário tratar de ao menos uma delas, em razão de sua imprescindibilidade "para presentar un campo de conocimiento de una manera más fácilmente comprensible o más rica en consecuencias prácticas deseables" $"$.

\subsubsection{Classificações propostas pela doutrina}

De início, recorre-se aos ensinamentos doutrinários de Bandeira de Mello ${ }^{81}$, segundo o qual, a interferência do Estado na ordem econômica pode ocorrer de três modos: (i) por meio de seu "poder de polícia", ou seja, na qualidade de agente normativo, regulador e fiscalizador da atividade econômica, em que o planejamento concebido constitui mera indicação para o setor particular e é determinante para o setor público (art. 174 da CF/1988); (ii) pelo exercício direto da atividade econômica, o que somente deve-se dar excepcionalmente e mediante a criação de pessoa específica para tal fim; e (c) por intermédio de incentivos concedidos à iniciativa privada (art. $174 \mathrm{da} C F / 1988$ ), sejam eles fiscais ou financeiros.

Maria Sylvia Zanella di Pietro ${ }^{82}$, nesse mesmo sentido, porém de forma mais objetiva, distingue os modos de intervenção em (i) direta, a qual consiste na atuação direta do Estado no domínio econômico, por meio, geralmente, das empresas estatais; e (ii) indireta, assim compreendida em face das atividades de regulamentação e fiscalização da atividade econômica privada.

De modo amplo, ao considerar que o Estado reconhece e assegura a propriedade privada e a liberdade de empresa de forma condicionada ao bem-estar coletivo, Hely Lopes Meirelles ${ }^{83}$ propõe uma classificação atrelada à atuação supletiva do Estado, a qual só se justifica como exceção à liberdade individual e desde que autorizada pela Constituição, destacando como principais meios de atuação na ordem econômica: (i) o monopólio; (ii) a repressão ao abuso do poder econômico; (iii) o controle do abastecimento; (iv) o tabelamento de preços; e (v) a criação de empresas estatais.

O autor em comento distingue duas formas de intervenção do Estado na atividade econômica: (i) no domínio econômico, a qual incide na atividade lucrativa

\footnotetext{
CARRIÓ, Genaro. Notas sobre derecho y lenguaje, p. 99.

MELLO, Celso Antônio Bandeira de. Curso de direito administrativo, p. 802.

82 DI PIETRO, Maria Sylvia Zanella. Direito administrativo, p. 56-57.

83 MEIRELLES, Hely Lopes. Direito administrativo brasileiro, p. 614.
} 
da empresa e recai sobre o produto do trabalho humano, atribuindo-lhe um aspecto dinâmico, que, por sua vez, constitui objeto de estudo do Direito Econômico; e (ii) na propriedade privada, apresentada na forma estática, pois recai sobre os bens localizados no território do Estado e constitui matéria afeta ao Direito Econômico.

Em termos constitucionais, Luís Roberto Barroso ${ }^{84}$ classifica a intervenção do Estado no domínio econômico por meio de três mecanismos: (i) a disciplina; (ii) o fomento; e (iii) a atuação direta, em que, respectiva e sinteticamente, atua como agente normativo e regulador, exercendo a função de fiscalização prevista no art. 174 da CF/1988; apoia a iniciativa privada e estimula (ou desestimula) determinados comportamentos e, por fim, assume diretamente o papel de produtor ou prestador de bens ou serviços.

Ainda na seara constitucional, José Afonso da Silva distingue a atuação estatal

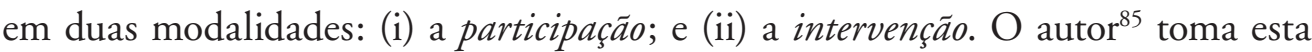
última em seu sentido restrito, segundo o qual:

A primeira com base nos arts. 173 a 177, caracterizando o Estado administrador de atividades econômicas; a segunda fundada no art. 174, em que o Estado aparece como agente normativo e regulador da atividade econômica, que compreende as funções de fiscalização, incentivo e planejamento, caracterizando o Estado regulador, o Estado promotor e o Estado planejador da atividade econômica. (Grifo do original.)

Eros Grau ${ }^{86}$, por sua vez, prefere distinguir a presença do Estado no sistema econômico em três modalidades: (i) intervenção por absorção ou participação; (i) intervenção por direção; e (iii) intervenção por indução.

Com isso, tem-se que, na primeira modalidade, a intervenção dar-se-ia no domínio econômico em que o Estado atua como se fosse um agente econômico, assumindo ou participando na gestão ou controle do capital de uma unidade econômica que detenha o controle patrimonial dos meios de produção e de troca.

Ao realizar a intervenção por absorção, "o Estado assume integralmente o controle dos meios de produção e/ou troca em determinado setor da atividade econômica em sentido estrito; atua em regime de monopólio", ao passo que, na intervenção por participação, "assume o controle de parcela dos meios de produção e/ou troca em determinado setor da atividade econômica em sentido estrito; atua em regime de

84 BARROSO, Luís Roberto. Modalidades de intervenção do Estado na ordem econômica. Regime jurídico das sociedades de economia mista. Inocorrência de abuso de poder. In: Temas de direito constitucional. Rio de Janeiro: Renovar, 2001. p. 395.

85 SILVA, José Afonso da. Curso de direito constitucional positivo, p. 785.

86 GRAU, Eros Roberto. A ordem econômica na Constituição de 1988, p. 146 e ss. 


\section{•• O orçamento como instrumento de intervenção no domínio econômico}

competição com empresas privadas que permanecem a exercitar suas atividades nesse mesmo setor" ${ }^{\prime \prime 7}$.

Em ambas as modalidades - intervenção por absorção e intervenção por participação -, o Estado ou exerce diretamente a atividade econômica, em regime de monopólio estatal, legal ou de fato, ou o faz por intermédio de uma entidade criada para tanto, cuja empresa estatal misturar-se-á com as demais, sem perder, contudo, a sua capacidade de influência ${ }^{88}$.

Nas duas outras modalidades, ou subespécies - intervenção por direção e intervenção por indução -, verificar-se-ia a intervenção sobre o domínio econômico, na qual o Estado intervém sobre o campo de atividade econômica em sentido estrito na qualidade de regulador de determinada atividade, fazendo-o, assim como o próprio nome sugere, por direção ou por indução.

Ao fazê-lo por direção, o Estado pressiona a economia valendo-se de mecanismos e normas de comportamento compulsório que atingem diretamente os sujeitos da atividade econômica. Nesse tipo de intervenção permite-se tão somente o comportamento previsto na norma, a qual, descumprida, acarretará determinada sanção jurídica, como, por exemplo, a imposição de pagamento de multa.

Fábio Nusdeo propõe uma classificação mais política e econômica do que jurídica, ao enumerar as formas de intervenção do Estado no domínio econômico de acordo com o instrumento público econômico utilizado, intervenção essa que seria feita mediante: (i) instrumentos de finanças públicas; (ii) instrumentos monetários e creditícios; (iii) instrumentos cambiais; (iv) instrumentos de controle direto; e (v) adaptação institucional.

De acordo com a classificação proposta pelo referido autor, os três primeiros instrumentos, identificados pelos itens (i), (ii) e (iii), correspondem a uma ação eminentemente indireta da política econômica, pois, mediante estímulos ou punições de caráter fiscal, monetário e cambial, o Estado intervém ou influencia o comportamento do mercado ${ }^{89}$.

$\mathrm{O}$ item (iv), instrumentos de controle direto, destina-se a determinar certas variáveis do sistema econômico, que ocorrerão, dentre outras, com a fixação de preços e de salários, o contingenciamento do comércio exterior, o estabelecimento de cotas de produção, o racionamento, a determinação da taxa cambial etc. ${ }^{90}$

\footnotetext{
GRAU, Eros Roberto. A ordem econômica na Constituição de 1988, p. 147.

NUSDEO, Fábio. Curso de economia: introdução ao direito econômico, p. 197.

89 NUSDEO, Fábio. Curso de economia: introdução ao direito econômico, p. 194-195.

90 NUSDEO, Fábio. Curso de economia: introdução ao direito econômico, p. 195.
} 
Por fim, o item (v), adaptação institucional, consistiria em um tipo de ação propedêutica às demais, pois se dá mediante a criação de uma legislação adequada e de órgãos e instituiçôes destinadas a legitimar a utilização de todos os outros instrumentos ${ }^{91}$ mencionados.

$\mathrm{Na}$ doutrina comparada, com merecido destaque ao critério proposto pelo autor lusitano Luís S. Cabral de Moncada ${ }^{92}$, as intervenções do Estado no domínio econômico são classificadas: (i) quanto a sua abrangência - intervençôes globais, setoriais e pontuais (avulsas); (ii) quanto aos seus efeitos - intervençóes imediatas e mediatas; (iii) quanto à manifestação de vontade - intervenções unilaterais e bilaterais; e (iv) quanto à atuação do Estado - intervenções diretas e indiretas.

De modo sintético, as intervençôes globais distinguem-se das intervenções setoriais pelo fato de estarem relacionadas com a economia e de se verificarem quando o Estado adota normas gerais de fixação de margem de comercialização ou encorajamento do investimento global, ao passo que as setoriais se restringem à adoção de medidas destinadas a desenvolver um setor específico da economia, como o turismo, a agricultura, a siderurgia etc.

Na hipótese de o Estado intervir diretamente na economia, perseguindo objetivos especificamente econômicos em que exerce seu poder de polícia ou adota medidas de fomento à economia, estar-se-á diante do modo de intervenção imediata. Se, todavia, as medidas adotadas não têm apenas objetivos econômicos, mas repercutem na economia, como, por exemplo, nos casos de adoção de medidas de política fiscal, realização de operaçōes de open market, definição de certos regimes jurídicos etc., tratar-se-á de intervenção mediata, sobre a economia e não na economia ${ }^{93}$.

As intervenções unilaterais, por sua vez, consistem na proibição ou autorização de determinadas atividades e, em geral, são impostas por meio de regulamentos e atos administrativos. Essa modalidade de intervenção se opõe às intervenções bilaterais, que conformam intervenções estatais por via contratual ${ }^{94}$, ou seja, formas

91 NUSDEO, Fábio. Curso de economia: introdução ao direito econômico, p. 195.

92 MONCADA, Luís S. Cabral de. Direito económico, p. 41-47.

93 MONCADA, Luís S. Cabral de. Direito económico, p. 46.

94 É oportuno observar que o autor se refere ao termo "contrato" de forma genérica, pois bem adverte que "não significa que todos estes instrumentos sejam, sob o ponto de vista da teoria jurídica, autênticos contratos". Afinal, ainda hoje, remanescem controvérsias na doutrina a respeito dos chamados "contratos administrativos", havendo, de acordo com Maria Sylvia Zanella di Pietro, ao menos três correntes: (i) a que nega a existência do contrato administrativo; (ii) a que afirma que todo contrato firmado pela Administração Pública é um contrato administrativo; e (iii) a que aceita a existência dos contratos administrativos como espécie do 


\section{•• O orçamento como instrumento de intervenção no domínio econômico}

convencionais do exercício da autoridade que dependem da prévia e espontânea adesão do particular" ${ }^{95}$. Para exemplificar, Luís S. Cabral de Moncada cita, dentre outros, (i) a oferta pelos poderes públicos de certas vantagens fiscais ou creditícias, concedidas em troca da execução por determinadas empresas privadas de determinada política de investimento; e (ii) a assinatura de contratos-programa, contratos de desenvolvimento, contratos de viabilização, contratos de investimento estrangeiro etc.

Esclarece ainda referido autor, que a intervenção indireta no direito econômico se dá quando o Estado - por si ou por interposta pessoa - não é o titular efetivo da exploração econômica, pois, caso contrário, a intervenção será direta, isto é, quando o Estado ou outra entidade pública seja o titular real da exploração da atividade econômica.

Por fim, na intervenção indireta o Estado age dirigindo ou controlando as atividades econômicas privadas na qualidade de agente fiscalizador (função de polícia) ou de estímulo (função de fomento), de modo a atender aos interesses públicos. $\mathrm{Na}$ intervenção direta, o Estado assume o papel de agente produtivo, criando empresas públicas ou controlando sociedades econômicas por meio das quais atua e intervém no processo de produção e distribuição, a qual se aplica na regulamentação do mercado, em que se dá a assunção total ou parcial de determinadas atividades ${ }^{96}$.

A doutrina francesa, com merecido destaque para a obra de André de Laubadère ${ }^{97}$, também se vale desse mesmo critério de classificação, proposto por Luís $S$. Cabral de Moncada.

Como é possível notar, diversas são as classificações propostas, dando origem a inúmeras facetas. Alguns doutrinadores simplesmente distinguem a presença do Estado no domínio econômico em direta e indireta, ao passo que outros se limitam a propor uma releitura do texto constitucional e outros, ainda, preferem ir mais a fundo, ao apresentar subespécies e diferenciá-las quanto a sua abrangência e efeitos.

\subsubsection{Classificação adotada}

As inúmeras classificações apontadas demonstram que há uma grande diversidade dos modos de intervenção do Estado na economia e, mais especificamente,

gênero contrato, com regime jurídico de Direito Público (DI PIETRO, Maria Sylvia Zanella. Direito administrativo, p. 260-262).

95 MONCADA, Luís S. Cabral de. Direito económico, p. 42-43.

96 MONCADA, Luís S. Cabral de. Direito económico, p. 45.

97 LAUBADÈRE, André de. Direito público económico, p. 29 e ss. 
no domínio econômico, e que elas nem sempre se distinguem ou são apresentadas de maneira clara.

Por isso, a dificuldade em eleger uma delas em específico, ainda que se note, nos próximos capítulos, que, de certa maneira, todas as classificações propostas guardam relação direta ou indireta com o objeto do presente estudo. Em outras palavras, ao tratar das receitas, despesas e crédito público, a percepção de que todas elas possuem correlação com o orçamento público e o poder de impactar não apenas a economia de modo geral, mas na atividade desenvolvida pelo particular, seja para restringi-las, seja para fomentá-las, dar-se-á intuitivamente, assim como seus reflexos na sociedade.

Ao tomar-se em conta referidos fatores e tendo-se como caráter distintivo o objeto desta dissertação, remanescerão dúvidas não mais acerca da instrumentalidade do orçamento público, mas no que concerne à sua efetividade, qualidade e eficiência em seu emprego como instrumento de intervenção no domínio econômico. Afinal, procura-se avaliar se o Estado, aqueles que o administram e a própria iniciativa privada têm a clareza de sua importância e dos limites a serem respeitados.

Ademais, e embora a vida econômica seja regida por princípios naturais que não devem ser embaraçados pelo Estado - prevalência da iniciativa privada no plano da atividade econômica (art. 173 da CF/1988) -, também, faz-se necessário reprimir abusos e, com isso, intervir com o propósito de regulamentar determinadas atividades (art. $174 \mathrm{da} C F / 1988$ ) ou espaldar a iniciativa particular fraca ou insuficiente, tendo por finalidade alcançar os objetivos delimitados na Constituição brasileira, os quais se traduzem nos anseios da sociedade.

Persegue-se, portanto, uma classificação que aponte para essas características, melhor dizendo, que seja capaz de demonstrar a relevância e importância do orçamento público também para a iniciativa privada e a necessidade de cobrar mais daqueles que detêm o munus publico de cumpri-lo fielmente.

Essa assertiva justifica-se em razão de, afinal, também ser por meio dos mecanismos ou ferramentas que o orçamento dispõe que o Estado se insere no domínio econômico privado com a finalidade de produzir resultados macro ou microeconômicos, diversos daqueles que adviriam caso não houvesse a intervenção, pois, ao praticá-la, persegue a alteração de parâmetros comportamentais originários do mercado no qual intervém, seja de forma promocional, restritiva ou repressiva ${ }^{98}$.

98 MOREIRA, Egon Bockmann. O direito administrativo contemporâneo e a intervenção do Estado no domínio econômico. In: WAGNER JUNIOR, Luiz Guilherme da Costa (Coord.). Direito público: estudos em homenagem ao professor Adilson de Abreu Dallari. Belo Horizonte: Del Rey, 2004. p. 257-282. 
Logo, diante de todas as classificações anteriormente descritas, procura-se uma que seja capaz de demonstrar, de um lado, sua amplitude ou alcance e, de outro, os efeitos que a intervenção do Estado possa produzir - ou que se espera que produza - no domínio econômico.

Também eleito o orçamento público como o instrumento público utilizado para movimentar o domínio econômico e sem nenhum propósito de inovar, pois não existem classificaçōes certas ou erradas, mas úteis ou inúteis, como adverte Genaro Carrióo 9 , sugere-se classificar as intervenções do Estado no domínio econômico em (i) intervenção por direção e (ii) intervenção por indução ou de fomento, bem como distingui-las em gerais, setoriais ou pontuais.

$\mathrm{Na}$ intervenção por direção, as medidas adotadas no orçamento terão como propósito atender às finalidades da lei, orientando ou restringindo a atividade econômica desempenhada por empresas públicas ou privadas, agindo o Estado de forma direta ou indireta, ou seja, explorando diretamente a atividade econômica por meio do monopólio ou com a criação de empresas públicas ou mistas; ou adotando medidas regulatórias ou fiscalizatórias, no exercício regular de seu poder de polícia. É o que se verifica, por exemplo, quando o Estado se vale das receitas públicas tributárias para dirigir ou regular determinados comportamentos, aumentando ou reduzindo a carga tributária.

Já na intervenção por indução ou de fomento, o Estado, por meio do orçamento público, promove o desenvolvimento da economia, favorece a iniciativa privada criando estímulos ou incentivos que forcem os agentes a adotar determinadas condutas impossíveis de serem implementadas, caso não existisse a intervenção estatal.

Essas condutas se verificam, principalmente, quando o Estado prevê a concessão de benefícios fiscais, a contração de dívidas com o propósito de realizar investimentos públicos, a abertura de linhas de crédito ao setor privado etc.

Em face da divisão estabelecida e dos propósitos a serem demonstrados neste livro, torna-se necessário tratar da amplitude ou alcance dos efeitos das intervenções perpetradas pelo Estado, mais especificamente pela União Federal, as quais se dividem, de acordo com Laubadère ${ }^{100}$, em globais, setoriais e pontuais. Distinguem-se, assim, em:

(...) intervenções que afetam a economia em seu conjunto (intervenções globais) ou num determinado sector apenas (sectoriais), tendo umas e outras como traço comum o facto de serem gerais, e, por outro lado, as intervençôes pontuais, que dizem respeito a uma situação particular, por exemplo uma empresa.

99 CARRIÓ, Genaro. Notas sobre derecho y lenguaje, p. 99.

${ }^{100}$ LAUBADÈRE, André de. Direito público económico, p. 28. 
Conforme poderá ser constatado adiante, ao conceder crédito ou subvenções econômicas a determinado setor - turismo, agricultura, sucroalcooleiro, siderúrgico etc. -, estar-se-á perante uma intervenção setorial de fomento, pois o Estado se vale de sua receita pública ou da realização de despesas para incentivar determinadas e específicas atividades conferidas à iniciativa privada.

Ambas as intervenções - globais e setoriais -, portanto, diferem da intervenção pontual que se dá quando o Estado firma diretamente com determinada empresa um contrato de viabilização, convênios administrativos ${ }^{101}$, parcerias público-privadas ${ }^{102}$ ou, até mesmo, quando injeta capital em uma empresa específica com o propósito de evitar sua quebra, estatizando-a ou não. Neste último aspecto, é importante mencionar a posição de Luís S. Cabral de Moncada ${ }^{103}$, segundo o qual, referidas intervenções devem respeitar critérios estratégicos gerais e de ordem objetiva.

De acordo com a peça orçamentária e a leitura que a iniciativa privada venha a fazer dela, pode optar por investir nos planos do Estado ou não. No caso de haver disponibilidade de recursos públicos a serem empregados em determinadas áreas ou setores, o Estado, ainda que tenha agido sem esse propósito, poderá influenciar a iniciativa privada, de forma global, setorial ou pontual, a adotar medidas positivas e, assim, realizar investimentos que vão desde a capacitação e contratação de mão de obra até a aquisição de bens e materiais, ou, de outro modo, a adotar medidas negativas que possam redundar na restrição de investimentos e contenção de despesas e, portanto, efeitos indesejáveis.

Como adverte John Maynard Keynes, é possível "que as eventuais modificações da política fiscal tenham, pelo menos, nas expectativas, maior influência do

101 De acordo com Hely Lopes Meirelles, "Convênios administrativos são acordos firmados por entidades públicas de qualquer espécie, ou entre estas e organizações particulares, para realização de objetivos de interesse comum dos partícipes." (MEIRELLES, Hely Lopes. Direito administrativo brasileiro, p. 386).

102 Instituídas pela Lei n. 11.079/2004, alterada pela Lei n. 11.409/2011, e pela Medida Provisória n. 575/2012, posteriormente convertida na Lei n. 12.766/2012, as parcerias público-privadas constituem uma das modalidades de contrato administrativo e, embora existam várias espécies, a referida Lei n. 11.079 , no art. $2^{\circ}$, reservou a expressão para apenas duas modalidades específicas: "parceria público-privada é o contrato administrativo de concessão, na modalidade patrocinada ou administrativa". Em suma, como esclarece Maria Sylvia Zanella di Pietro, "pode-se dizer que a parceria público-privada é o contrato administrativo de concessão que tem por objeto (a) a execução de serviço público, precedida ou não de obra pública, remunerada mediante tarifa paga pelo usuário e contraprestação pecuniária do parceiro público, ou (b) a prestação de serviço de que a Administração Pública seja a usuária direta ou indireta, com ou sem execução de obra e fornecimento e instalação de bens, mediante contraprestação do parceiro público" (DI PIETRO, Maria Sylvia Zanella. Direito administrativo, p. 315-316).

103 MONCADA, Luís S. Cabral de. Direito económico, p. 41-42. 


\section{•• O orçamento como instrumento de intervenção no domínio econômico}

que a própria taxa de juro"104. Na atualidade, e levando em consideração as ideias de John Maynard Keynes, pode-se dizer que o orçamento, ao estampar a política fiscal do governo, produz expectativas positivas ou negativas, influenciando o domínio econômico na tomada de decisóes que impactarão a economia e o próprio desenvolvimento econômico.

O que se vê é que as pretensões do Estado, traduzidas no orçamento público, podem gerar efeitos tanto positivos quanto negativos, a depender de seu planejamento, conforme demonstrado adiante.

Por fim, não se pode perder de vista o fato de que, qualquer medida a ser adotada pelo Estado deverá ser tomada em conformidade com a lei e com os objetivos fixados no pacto social, ou seja, na Constituição Federal brasileira.

\subsection{INTERVENÇÃO, IDEOLOGIA E DOMINAÇÃO}

Como demonstrado, o Estado, legitimamente representado e na qualidade de agente normativo e regulador da atividade econômica, bem como fundado na valorização do trabalho humano e na livre iniciativa, justifica o exercício do poder de intervir no domínio econômico, o qual deve dar-se em consonância com os propósitos traçados na Constituição Federal, e desde que com observância dos princípios enumerados no art. 170.

Embora a Constituição brasileira anuncie a instituição de um Estado capaz de assegurar a harmonia social comprometida com a ordem interna e internacional sob os valores da justiça, não há como negar que inúmeros fatores - sociais, econômicos e políticos - acabam influenciando a alteração da posição do Estado perante a sociedade e repercutindo na forma de governo.

Os objetivos impostos pela Constituição ao Estado são realizados por este com supedâneo no arcabouço jurídico capaz de legitimar suas ações. A regulação jurídica, em seu todo, mostra-se, muitas vezes, meramente aparente quando se vai além do pensamento que se está condicionado a realizar, uma vez que restrito a uma realidade jurídica autônoma e exclusiva. Afinal, os Estados mais fortes dispõem de meios para modificar o direito quando isso lhes convém ${ }^{105}$, independentemente da vontade de seu povo.

Atento a essa questão, Hobbes, ao tratar da essência do Estado, define-o como sendo "uma pessoa instituída, pelos atos de uma grande multidão, mediante pactos

104 KEYNES, John Maynard. Teoria geral do emprego, do juro e da moeda, p. 85.

105 DALLARI, Dalmo de Abreu. Elementos de teoria geral do estado. 31. ed. São Paulo: Saraiva, 2012. p. 260. 
recíprocos uns com os outros, como autora, de modo a poder usar a força e os meios de todos, da maneira que achar conveniente, para assegurar a paz e a defesa comum"106.

Com efeito, o pacto social defendido por Thomas Hobbes se traduz em um documento solene cujos termos foram discutidos em assembleia e que, atualmente, denomina-se Constituição; esta, por sua vez, define, de acordo com cada Estado e seu momento histórico, sua estrutura, atribuições e limites. Em suma, estabelece o pacto solene já mencionado e com o qual se concorda em parte com a posição do filósofo, pois não se pode aceitar que esta compreenderia a renúncia ampla e irrestrita de direitos, dentre os quais se destaca a liberdade.

De qualquer modo, e ainda que uma multidão confira plena força e poder a um homem, ou a uma assembleia de homens, como proposto por Thomas Hobbes, e mesmo que esse possa parecer o caminho capaz de defendê-los das invasões estrangeiras e das injúrias que uns possam fazer aos outros, reconhecendo cada membro dessa multidão como autor dos atos que aquele(s) que o representa $(\mathrm{m}) \operatorname{possa}(\mathrm{m})$ praticá-lo em seu nome, em evidente ato de cessão do direito de governar a si mes$\mathrm{mo}^{107}$, é impossível aceitar que o faça em nome de todos.

Representante de uma maioria e não da totalidade, aquele que age em nome do Estado em determinado momento histórico inevitavelmente acaba praticando atos indicadores do propósito de assegurar a manutenção do poder ou defender seus interesses privados, ideias e ideais, ou, até mesmo, daqueles que o apoiam ou cercam.

Esteja-se, portanto, diante de um Estado político, ou por instituiçãa, como denominou Thomas Hobbes ${ }^{108}$, interesses divergentes, conflitantes e digressivos sempre existirão. Os homens se envolvem com recorrência em competição pela honra e pela dignidade; só encontram a felicidade na comparação com os outros homens e, ainda, julgam-se mais sábios e mais capacitados que os demais para o exercício do Poder Público ${ }^{109}$.

Em razão do exposto, ao tratar da intervenção do Estado no domínio econômico, é preciso analisá-la de maneira a ir além do paradigma axiomático proposto

${ }^{106}$ HOBBES, Thomas. Leviatã, ou matéria, forma e poder de um estado eclesiástico e civil. Traduzido por Rosina D’ Angina. 2. ed. São Paulo: Martin Claret, 2012. p. 140. (Coleção A obra prima de cada autor).

107 HOBBES, Thomas. Leviatã, ou matéria, forma e poder de um estado eclesiástico e civil, p. 140.

${ }^{108}$ HOBBES, Thomas. Leviatã, ou matéria, forma e poder de um estado eclesiástico e civil, p. 141.

${ }^{109}$ HOBBES, Thomas. Leviatã, ou matéria, forma e poder de um estado eclesiástico e civil, p. 139. 


\section{•• O orçamento como instrumento de intervenção no domínio econômico}

e, com isso, apresentar uma visão de natureza axiológica, para que se possa entender a intervenção do Estado não apenas como decorrência de mera previsão legal, mas, também, como resultado da evolução do pensamento e da história.

$\mathrm{O}$ detentor de poder que lhe foi atribuído pelo Estado exerce-o na qualidade de dominante ou dominador. Para coibir o uso indiscriminado da força, o sistema jurídico simplesmente tenta impor limites aos seus detentores, evitando, assim, a "guerra de todos contra todos", de que falava Thomas Hobbes.

Mais ainda. Esse poder, de acordo com Michel Foucault, deve ser compreendido tomando-se em consideração os símbolos, rituais, liturgias e seus personagens, o seu método, ou, como prefere o filósofo, de sua genealogia, isto é, por meio de "pesquisas genealógicas múltiplas, ao mesmo tempo redescoberta exata das lutas e memória bruta dos combates"110.

Como proposto por Michel Foucault, é preciso atentar para o que se faz e para as desculpas que se dá ao justificar o que se faz no exercício do poder, pois este detém funcionalidade econômica ao ser dotado, essencialmente, do papel de manter relações de produção e reproduzir uma dominação de classe que o desenvolvimento constitui uma modalidade própria da apropriação das forças produtivas, tornando-as possíveis.

O poder se sustenta na obediência submissa dos liderados. No entanto, as estratégias para a conquista e manutenção do poder não se resumem apenas às regras de como subjugá-los.

$\mathrm{O}$ indivíduo que detém o poder ou o almeja alcançar nem sempre o faz com o propósito de atingir determinada posição de prestígio, ou age com o intuito de se enriquecer. Como mostra Michel Foucault, a luta travada vai além - trava-se a luta pelos saberes, pela consagração das condições de possibilidade de dominação. Luta-se, enfim, pela difusão, manutenção ou alteração de determinados saberes e não por cargos, benefícios ou status sociais.

A propósito, Baruch de Espinosa já dizia que "o direito do soberano, como o do indivíduo, no estado de natureza, mede-se pelo seu poder" ${ }^{\prime 11}$. Ainda segundo o autor $^{112}$ :

110 FOUCAULT, Michel. Microfísica do poder. Organização, introdução e revisão técnica de Roberto Machado. 25. ed. São Paulo: Graal, 2012. p. 267.

111 SPINOZA, Baruch de. Tratado político. Tradução e prefácio de José Pérez. Edição especial. Rio de Janeiro: Nova Fronteira, 2013. p. 47.

112 SPINOZA, Baruch de. Tratado politico. Tradução e prefácio de José Pérez. Edição especial. Rio de Janeiro: Nova Fronteira, 2013. p. 41. 
(...) um homem tem outro sob seu poder, quando o tem preso, ou quando lhe arrebatou as armas e os meios de defender-se ou de evadir-se, ou, ainda, quando o domina pelo medo, ou, enfim, quando o domina de tal modo pelos benefícios, que fá-lo obedecer aos caprichos do seu benfeitor, de preferência às suas próprias inclinações e viver à discrição deste, mais que pelas inclinações da sua própria vontade.

Os fatos apresentados justificam anuir com o posicionamento de Max Weber, segundo o qual a dominação constitui um dos elementos mais importantes da ação social ${ }^{113}$ e, ainda, embora nem toda forma de ação social revele uma estrutura de domínio, todas as suas esferas sofrem profunda influência das estruturas de dominação, pois sua estrutura e seus desdobramentos são decisivos na determinação da forma da ação social e destinadas a determinado objetivo ${ }^{114}$.

Ao se referir ao termo dominação como sendo o desejo manifestado (ordem) pelo(s) líder(es) em influenciar a conduta de um ou mais liderados, chamando-a, se vista pelo outro lado, de obediência ${ }^{115}$, Weber afirma ser a dominação um caso especial de poder em que o dominador, ao exercê-la, não a aplica tão somente para atingir propósitos puramente econômicos, mesmo sendo estes uma consequência frequente e um de seus instrumentos mais importantes ${ }^{116}$.

Max Weber ${ }^{117}$ classifica a dominação em: (i) legal ou legal-racional; (ii) tradicional; e (iii) carismática.

A dominação legal é a mais estável, pois se baseia em normas que podem ser criadas e modificadas a qualquer tempo, e desde que legitimamente instituídas. Tem a "burocracia" como seu tipo mais puro e como princípio fundamental a hierarquia funcional, cuja obediência se presta não à pessoa que detém o poder, mas ao cargo estatuído.

113 Weber cita quatro tipos de ação social: (i) ação social tradicional, em que o indivíduo a toma de modo automático, sem pensar para realizá-la; (ii) ação social afetiva, em que a participação do emocional do agente é maior que seu racional (por exemplo, relações familiares); (iii) ação social racional quanto aos valores, em que se requer do indivíduo uma ética da convicção, um senso de missão a cumprir em função dos valores que preza; e (iv) ação social racional quanto aos fins, em que o indivíduo avalia, levando em consideração os fins que pretende atingir e os meios disponíveis para isso, se a ação que pretende realizar vale a pena, consideradas as dificuldades a serem enfrentadas (WEBER, Max. Economia e sociedade. Trad. de Regis Barbosa e Karen Elsabe Barbosa, rev. téc. de Gabriel Cohn. Reimpressão. Brasília: Editora UnB, 1999. v. II, p. 187 e ss.).

114 WEBER, Max. O direito na economia e na sociedade, p. 295-296.

115 WEBER, Max. O direito na economia e na sociedade, p. 302.

116 WEBER, Max. O direito na economia e na sociedade, p. 296.

117 WEBER, Max. Economia e sociedade: fundamentos da sociologia compreensiva. Trad. por Regis Barbosa e Karen Elsabe Barbosa; rev. téc. de Gabriel Cohn. Brasília: Reimpressão. Editora UnB, 1999, 2009. v. I, p. 139-161. 
Esse modelo de dominação aplica-se inteiramente ao Estado moderno, em que o governante eleito passa a exercer o poder por conta do cargo que assume, o qual não é atribuído à sua pessoa. Ao término do mandato, o poder desse governante permanecerá atrelado ao cargo estabelecido ou criado por um estatuto (uma norma), permitindo que outra pessoa, posteriormente, assuma o mesmo cargo e a responsabilidade pelo poder.

$\mathrm{Na}$ dominação tradicional, a autoridade é pura e simplesmente suportada pela existência de uma fidelidade tradicional. O governante é o patriarca ou o senhor, os dominados são os súditos, e o funcionário é o servidor. Nesse modelo, presta-se obediência à pessoa por respeito, em virtude da tradição de uma dignidade pessoal que se julga sagrada.

Todo o comando dessa modalidade de dominação se prende intrinsecamente à tradição e não a normas, classificando-a Max Weber como sendo uma dominação estável, em razão da solidez e estabilidade do meio social que se acha sob a dependência direta e imediata do aprofundamento da tradição na consciência coletiva.

$\mathrm{Na}$ dominação carismática, a autoridade é suportada graças à devoção afetiva dos dominados. Assenta-se sobre as "crenças" transmitidas por profetas, sobre o "reconhecimento" que pessoalmente alcançam os heróis e os demagogos, durante as guerras e revoluçõos, nas ruas e nas tribunas. A fé e o reconhecimento são convertidos em deveres invioláveis que lhes são devidos pelos governados, mostrando-se, assim, instáveis por não haver nada capaz de assegurar sua perpetuação.

\section{Max Weber ${ }^{118}$ conclui:}

Toda administração precisa, de alguma forma, da dominação, pois, para dirigi-la, é mister que certos poderes de mando se encontrem nas mãos de alguém. $\mathrm{O}$ poder de mando pode ter aparência muito modesta, sendo o dominador considerado o "servidor” dos dominados e sentindo-se também como tal. Isso ocorre, em mais alto grau, na chamada administração democrática.

Cada dominante, a todo instante e com o intuito de subjugar a maioria, de se manter no poder, vale-se de sua ideologia e tenta impor aos membros da sociedade o que devem pensar, sentir, valorizar, fazer ou deixar de fazer e, com isso, justificar suas ações ou omissões. Neste ponto, é pertinente trazer à colação o conceito de ideologia empregado pela filósofa Marilena Chauí ${ }^{119}$, segundo a qual:

118 WEBER, Max. Economia e sociedade: fundamentos da sociologia compreensiva, p. 193.

119 CHAUÍ, Marilena. Manifestaçôes ideológicas do autoritarismo brasileiro. Organizado por André Rocha. Belo Horizonte: Autêntica; São Paulo: Fundação Perseu Abramo, 2013. (Escritos de Marilena Chauí, 2), p. 117. 
A ideologia é um conjunto lógico, sistemático e coerente de representações (ideias e valores) e de normas ou regras (de conduta) que indicam e prescrevem aos membros de uma sociedade o que devem pensar e como devem pensar, o que devem valorizar e como devem valorizar, o que devem sentir e como devem sentir, o que devem fazer e como devem fazer. Ela é, portanto, um conjunto de ideias ou representações com teor explicativo (ela pretende dizer o que é a realidade) e prático ou de caráter prescritivo, normativo, regulador, cuja função é dar aos membros de uma sociedade dividida em classes uma explicação racional para as diferenças sociais, políticas e culturais, sem jamais atribuí-las à divisão da sociedade em classes, determinada pelas divisões na esfera da produção econômica. Pelo contrário, a função da ideologia é ocultar a divisão social das classes, a exploração econômica, a dominação política e a exclusão cultural, oferecendo aos membros da sociedade o sentimento de uma mesma identidade social, fundada em referenciais unificadores como, por exemplo, a Humanidade, a Liberdade, a Justiça, a Igualdade, a Nação.

Em síntese, o dominador utiliza o discurso universal, o imaginário, não no sentido de irrealidade ou fantasia, mas de um conjunto de imagens ou representações sistematizadas com coerência, para justificar uma suposta realidade concreta, provocando inversão entre o "de direito" e o "de fato".

Além disso, o dominador fornece aos sujeitos sociais e políticos um espaço de ação que vai além do corpus de representação coerente para explicar o real, dando-lhes um corpus de normas coerentes para orientar a prática, formada de regras corretas para a açãa ${ }^{120}$.

Sustenta-se o discurso ideológico justamente porque "não pode dizer até o fim aquilo que pretende dizer. Se o disser, se preencher todas as lacunas, ele destruirá a si mesmo como ideologia. A força do discurso ideológico provém de uma lógica que poderíamos chamar de lógica de lacuna, lógica do branco, lógica do silêncio"

E, como bem salienta Regis Fernandes de Oliveira, "a dominação tomou rumos refinados e se impõe à vontade do outro através de ritos sacrificais sofisticados"122.

Com efeito, nada mais significativo que a possibilidade de intervir na atividade exercida pela iniciativa privada para demonstrar o poder e impor desejos particulares - seja na qualidade de representante da coletividade, seja na qualidade de representante do Estado, valem-se todos do "interesse público", da Nação, da Pátria, do Progresso, da Família, do próprio Estado, enfim, "de uma referência

${ }^{120}$ CHAUÍ, Marilena. Manifestaçôes ideológicas do autoritarismo brasileiro, p. 124-126.

121 CHAUÍ, Marilena. Manifestaçôes ideológicas do autoritarismo brasileiro, p. 127.

122 OLIVEIRA, Regis Fernandes de. Gastos públicos, p. 137. 


\section{•• O orçamento como instrumento de intervenção no domínio econômico}

unificadora ideológica" como justificativa ou argumento hábil à prática de determinados atos de vontade, escamoteando "a percepção de um império dos homens sobre os homens"123.

As ideais dominantes de uma época são as da classe então dominante. Aparecem como representação do real e como verdade para os dominadores, como normas para a ação, tendo como pressuposto atender a certos fins, que seriam os mesmos para todos ${ }^{124}$.

Como lembra Paulo Freire ${ }^{125}$, há um ciclo ad infinitum.

$\mathrm{O}$ autor afirma ${ }^{126}$ que, quando a superação

(...) se realiza em termos autênticos, com a instalação de uma nova situação concreta, de uma nova realidade inaugurada pelos oprimidos que se libertam, é que os opressores de ontem não se reconheçam em libertação. Pelo contrário, vão sentir-se como se realmente estivessem sendo oprimidos.

Paulo Freire ${ }^{127}$ ainda diz:

$\mathrm{Na}$ análise da situação concreta, existencial, de opressão, não podemos deixar de surpreender o seu nascimento num ato de violência que é inaugurado, repetimos, pelos que têm poder.

Esta violência, como um processo, passa de geração a geração de opressores, que se vão fazendo legatários dela e formando-se no seu clima geral. Este clima cria nos opressores uma consciência fortemente possessiva. Possessiva do mundo e dos homens.

Mesmo que o Estado, ou aqueles que o representam, eleja qualquer uma das formas ou critérios de intervenção, seja pela absorção, participação, direção, fomento ou indução, a escolha dar-se-á em consonância com interesses pessoais, de acordo com suas convicçôes e, definitivamente, com o propósito de se perpetuar no poder, pois certa margem de liberdade ou discricionariedade ${ }^{128}$ sempre existirá, bastando, para tanto, beneficiar determinado grupo, aqueles que exerçam determinada atividade ou, ainda, convencer alguns de sua realidade.

123 CHAUÍ, Marilena. Manifestaçôes ideológicas do autoritarismo brasileiro, p. 128.

124 CHAUÍ, Marilena. Manifestaçôes ideológicas do autoritarismo brasileiro, p. 131.

125 FREIRE, Paulo. Pedagogia do oprimido. Rio de Janeiro: Nova Fronteira, 2012. p. 50.

${ }^{126}$ FREIRE, Paulo. Pedagogia do oprimido. Rio de Janeiro: Nova Fronteira, 2012. p. 50.

127 FREIRE, Paulo. Pedagogia do oprimido. Rio de Janeiro: Nova Fronteira, 2012. p. 50-51.

${ }^{128}$ No dizer de Bandeira de Mello, "fala-se em discricionariedade quando a disciplina legal faz remanescer em proveito e a cargo do administrador uma certa esfera de liberdade, perante o quê caber-lhe-á preencher com seu juízo subjetivo, pessoal, o campo de indeterminação normativa, a fim de satisfazer no caso concreto a finalidade da lei" (MELLO, Celso Antônio Bandeira de. Curso de direito administrativo, p. 970). 
Esses benefícios, como anotado por Weber, não necessariamente são econômicos, mas são facilmente percebidos quando alguém ou algum grupo ou instituição é contemplado com a concessão de um serviço público, incentivos fiscais, linhas de créditos, subvenções econômicas, subsídios, renúncias de receita etc., em detrimento de outros, pois não estão direta e intimamente ligados ao dominante.

Em suma, os dominantes recorrem a uma série de instrumentos para dominar, isto é, para "impor ao comportamento de terceiros a vontade própria"129 mediante carisma, afeto, hierarquia ou até mesmo em decorrência de um estatuto, ou seja, oriundo do cargo ocupado pelo dominante e do qual se utiliza para, e durante o período nele mantido, ditar regras, estabelecer normas e, com isso, beneficiar aqueles não só o apoiam, mas também lhe obedecem.

129 WEBER, Max. Economia e sociedade: fundamentos da sociologia compreensiva, p. 188. 
